NASA/TM-2003-212354

\title{
Fuel Cell Propulsion Systems for an All-Electric Personal Air Vehicle
}

\author{
Lisa L. Kohout
}

Glenn Research Center, Cleveland, Ohio

Paul C. Schmitz

Power Computing Solutions, Inc., Avon, Ohio 
Since its founding, NASA has been dedicated to the advancement of aeronautics and space science. The NASA Scientific and Technical Information (STI) Program Office plays a key part in helping NASA maintain this important role.

The NASA STI Program Office is operated by Langley Research Center, the Lead Center for NASA's scientific and technical information. The NASA STI Program Office provides access to the NASA STI Database, the largest collection of aeronautical and space science STI in the world. The Program Office is also NASA's institutional mechanism for disseminating the results of its research and development activities. These results are published by NASA in the NASA STI Report Series, which includes the following report types:

- $\quad$ TECHNICAL PUBLICATION. Reports of completed research or a major significant phase of research that present the results of NASA programs and include extensive data or theoretical analysis. Includes compilations of significant scientific and technical data and information deemed to be of continuing reference value. NASA's counterpart of peerreviewed formal professional papers but has less stringent limitations on manuscript length and extent of graphic presentations.

- TECHNICAL MEMORANDUM. Scientific and technical findings that are preliminary or of specialized interest, e.g., quick release reports, working papers, and bibliographies that contain minimal annotation. Does not contain extensive analysis.

- CONTRACTOR REPORT. Scientific and technical findings by NASA-sponsored contractors and grantees.
- CONFERENCE PUBLICATION. Collected papers from scientific and technical conferences, symposia, seminars, or other meetings sponsored or cosponsored by NASA.

- SPECIAL PUBLICATION. Scientific, technical, or historical information from NASA programs, projects, and missions, often concerned with subjects having substantial public interest.

- TECHNICAL TRANSLATION. Englishlanguage translations of foreign scientific and technical material pertinent to NASA's mission.

Specialized services that complement the STI Program Office's diverse offerings include creating custom thesauri, building customized databases, organizing and publishing research results ... even providing videos.

For more information about the NASA STI Program Office, see the following:

- Access the NASA STI Program Home Page at http://www.sti.nasa.gov

- E-mail your question via the Internet to help@sti.nasa.gov

- Fax your question to the NASA Access Help Desk at 301-621-0134

- Telephone the NASA Access Help Desk at 301-621-0390

- Write to:

NASA Access Help Desk

NASA Center for AeroSpace Information 7121 Standard Drive

Hanover, MD 21076 
NASA/TM-2003-212354

\section{Fuel Cell Propulsion Systems for an All-Electric Personal Air Vehicle}

Lisa L. Kohout

Glenn Research Center, Cleveland, Ohio

Paul C. Schmitz

Power Computing Solutions, Inc., Avon, Ohio

Prepared for the

International Air and Space Symposium and Exposition

cosponsored by the American Institute of Aeronautics and Astronautics and the International Council of the Aeronautical Sciences

Dayton, Ohio, July 14-17, 2003

National Aeronautics and

Space Administration

Glenn Research Center 
This report contains preliminary findings, subject to revision as analysis proceeds.

The Propulsion and Power Program at NASA Glenn Research Center sponsored this work.

Available from

NASA Center for Aerospace Information 7121 Standard Drive

Hanover, MD 21076
National Technical Information Service 5285 Port Royal Road Springfield, VA 22100

Available electronically at http:/ /gltrs.grc.nasa.gov 


\title{
FUEL CELL PROPULSION SYSTEMS FOR AN ALL-ELECTRIC PERSONAL AIR VEHICLE
}

\author{
Lisa L. Kohout \\ National Aeronautics and Space Administration \\ Glenn Research Center \\ Cleveland, Ohio 44135 \\ Paul C. Schmitz \\ Power Computing Solutions, Inc. \\ Avon, Ohio 44011
}

\begin{abstract}
There is a growing interest in the use of fuel cells as a power source for all-electric aircraft propulsion as a means to substantially reduce or eliminate environmentally harmful emissions. Among the technologies under consideration for these concepts are advanced proton exchange membrane and solid oxide fuel cells, alternative fuels and fuel processing, and fuel storage. This paper summarizes the results of a first-order feasibility study for an all-electric personal air vehicle utilizing a fuel cell-powered propulsion system. A representative aircraft with an internal combustion engine was chosen as a baseline to provide key parameters to the study, including engine power and subsystem mass, fuel storage volume and mass, and aircraft range. The engine, fuel tank, and associated ancillaries were then replaced with a fuel cell subsystem. Various configurations were considered including: a proton exchange membrane (PEM) fuel cell with liquid hydrogen storage; a direct methanol PEM fuel cell; and a direct internal reforming solid oxide fuel cell (SOFC)/turbine hybrid system using liquid methane fuel. Each configuration was compared to the baseline case on a mass and range basis.
\end{abstract}

Introduction

A multidisciplinary effort is underway at the NASA Glenn Research Center to develop and evaluate concepts for revolutionary, nontraditional fuel cell power and propulsion systems for aircraft applications. There is a growing interest in the use of fuel cells as a power source for electric propulsion as a means to substantially reduce or eliminate environmentally harmful emissions. Among the technologies under consideration for these concepts are advanced proton exchange membrane and solid oxide fuel cells, alternative fuels and fuel processing, and fuel storage. As part of this effort, system studies are being conducted to identify concepts with high payoff potential and associated technology areas for further development. Since the focus of the effort is on long-term, revolutionary concepts, the studies are being conducted to look at the ultimate potential of the fuel cell technology as opposed to the state-of-the-art performance. This paper summarizes the results of a first-order feasibility study that was performed for an allelectric personal air vehicle utilizing a fuel-cell powered propulsion system.

Considerations for Electric Propulsion Systems Fuel cells are an energy conversion device that transforms the chemical energy of a fuel and oxidant directly into usable electrical energy. Practically, a fuel cell is a device that: 1) strips electrons from one chemical species, leaving that species in a charged state; 2) makes electrons perform electrical work; 3) makes the charged species cross a barrier; and 4) returns the electrons, along with another chemical component to the charged species to form an entirely different chemical species. This process is shown schematically in Figure 1 for a PEM fuel cell. Electrons are stripped from the fuel, in this case hydrogen, at the anode to form a proton. The electrons are sent through a circuit to an external load while the proton passes through a membrane. At the cathode, the electrons recombine with the protons and oxygen from the air or another oxygen source to form water and heat. Single cells are coupled electrically to form stacks. The stacks along with the supporting ancillary equipment, such as pumps, compressors, and heat exchangers, form the fuel cell system.

Fuel cells offer many advantages over other power generating devices. Unlike batteries, 
fuel cells provide continuous power as long as fuel and oxidant are supplied. When operated on hydrogen, the byproducts of the fuel cell reaction are heat and water. Although large quantities of heat can be generated during operation, in many instances the heat can be recaptured and supplied to other processes, such as heating of reactants or fuel processing, or the hot exit streams can be expanded in a turbine to produce power.

For aeronautics applications, fuel cell system power density, defined as the power output per unit weight, is a critical parameter. Figure 2 shows a graph of the expected required increases in system power density to enable electric propulsion for various size aircraft. As can be seen from this chart, fuel cell development for the Gemini, Apollo, and Space Shuttle missions resulted in a 10-fold increase in power density over 18 years. Beginning in the early 1990's, significant investments from the automotive industry resulted in a 7 -fold increase over a span of 5 years. Current state-of-the-art technology performance is approximately $0.5 \mathrm{~kW} / \mathrm{kg}$ at the system level. Based on a one-to-one replacement of the current propulsion system with a fuel cell system, it is estimated that nearly a 20-times increase in power density is required to enable all-electric flight of a large commercial aircraft.

Another important consideration is the type of fuel to be used. The byproducts of the hydrogen reaction in a fuel cell are heat and water. While hydrogen is the fuel of choice from an environmental standpoint (zero emissions), there are some issues associated with its use for aircraft applications. Figure 3 compares the energy stored per unit volume for a variety of fuels. As can be seen from this chart, liquid hydrogen contains significantly less energy per unit volume than other liquid fuels. In addition, when comparing the volume required to store $1 \mathrm{~kg}$ of hydrogen (Figure 4), it can be seen that liquid hydrogen is much less volumetrically efficient, requiring up to $40 \%$ additional volume than the other fuels. However, while hydrocarbons and alcohols are more efficient in storing hydrogen, a fuel processing or reforming activity must take place, either internal or external to the fuel cell, to convert the hydrocarbon to usable hydrogen fuel. Since a byproduct of the reformation process is $\mathrm{CO}_{2}$, emissionless operation is compromised unless the $\mathrm{CO}_{2}$ is scrubbed from the exit stream.

The two main fuel cell types under consideration for aircraft applications are the PEM and the SOFC. Each of these systems offers distinct advantages as well as issues associated with their use in aircraft propulsion applications. PEM fuel cell technology is at a relatively high state of development due to major investments in recent years by the auto industry. PEM fuel cells operate at relatively low temperatures $\left(20\right.$ to $90^{\circ} \mathrm{C}$ ) and use a proton-conducting polymer membrane as an electrolyte. The anode and cathode are catalyzed porous electrodes bonded directly onto the membrane to form a single cell called a membrane electrode assemble (MEA). Cells are connected electrically in series with bipolar plates, which also serve to deliver and distribute the fuel and oxidant to the anode and cathode. For the most part, PEM fuel cells use hydrogen as the fuel, although some small direct methanol systems have been developed in which the methanol is reformed into hydrogen within the fuel cell. ${ }^{1}$ Being low temperature systems, PEM fuel cells cannot directly reform hydrocarbon fuels. Thus, if a PEM system were to be used with a hydrocarbon fuel, a separate fuel processing plant would be required. In addition, PEM systems require low sulfur and $\mathrm{CO}$ concentrations in the hydrogen stream to avoid contamination of the catalysts, adding to the complexity of the fuel processing.

The solid oxide fuel cell is an all-ceramic, hightemperature $\left(600\right.$ to $\left.1000{ }^{\circ} \mathrm{C}\right)$, solid-state device that uses an oxide ion conducting ceramic material as the electrolyte. The ceramic anode, electrolyte, and cathode materials are deposited in layers to form the solid oxide equivalent of the PEM MEA. There are two primary design types, tubular and planar. The tubular design was pioneered by the US Westinghouse Electric Corporation (now Siemens-Westinghouse) in the late 1970s and has been used primarily for stationary terrestrial powerplant applications. The more recent planar design resembles the PEM configuration in that the ceramic cells are stacked together in a bipolar configuration using metal or ceramic interconnects between the cells to provide a series connection, much like the PEM bipolar plate. The main 
advantage of the planar design over the tubular is that higher power densities can be achieved due to the lower losses inherent in the bipolar configuration. This is significant for mobile applications where mass and volume are typically limited. The planar design is, however, still at a low level of technology development as compared to either PEM or the tubular SOFC. Among the technology challenges that are currently being addressed in the industry are the thermal robustness of the ceramics, cell sealing at high temperatures, and cell scale-up. ${ }^{1}$

Although less technically mature, SOFCs offer some potential advantages over PEM fuel cells for aircraft applications. Due to its high operating temperature, the waste heat from the SOFC product stream can be extracted and used for other processes in the system such as fuel heating and reformation. The hot product stream can also be expanded through a turbine to extract power to run the fuel cell system ancillary equipment, such as pumps and air compressors. Unlike the PEM, SOFCs have the option to use $\mathrm{CO}$ as a fuel as well as hydrogen. Because of this $\mathrm{CO}$ tolerance, hydrocarbon fuels can be more readily used with less processing than in the PEM system. Also, with the high operating temperatures, SOFCs have the potential for direct internal reforming of light hydrocarbons. Direct natural gas reformation has been demonstrated in the tubular design and some work has been done in designing planar stacks with internal processing of natural gas. ${ }^{2-4}$ Additionally, SOFCs are more sulfur tolerant than PEM fuel cells, requiring less fuel processing to reduce sulfur levels.

\section{Study Methodology}

A top-level study was performed to assess the impact of liquid hydrogen-fueled PEM, direct methanol PEM, and direct reforming SOFChybrid fuel cell architectures on aircraft takeoff weight and range for a fuel cell-powered aircraft. The study expanded on the results of previous work by Freeh in which the Rotax 912 engine of a BanBi aircraft was replaced with an electric propulsion system consisting of a PEM fuel cell system with compressed hydrogen storage, an electric motor, and associated power management and distribution. The $\mathrm{BanBi}$ is a two-seat, single engine/prop light kit plane produced by American Ghiles Aircraft. Freeh concluded that, even with the elimination of additional payload capability, aircraft range was significantly less due to the tank volume and weight issues associated with compressed hydrogen storage. The weight statement for the reference $\mathrm{BanBi}$ aircraft with the Rotax 912 engine is given in Table 1. The range with the $60 \mathrm{~kW}(81 \mathrm{hp})$ Rotax was approximately $800 \mathrm{~nm} .^{5}$

The approach taken for the current study was to choose the BanBi with Rotax 912 engine as the baseline reference system. Based on the weight breakout in Table 1, the line items impacted by the conversion of the Banbi to electric propulsion were the engine and accessories, fuel tank, and fuel weight. The Rotax engine and accessories were replaced with a $60 \mathrm{~kW}$ (net) fuel cell propulsion system, which included the fuel cell stack, ancillaries, electric motor, and power conditioning. Fuel and tank weights were calculated based on a constraint of 88 liter total available volume, which corresponds to the BanBi tank volume. It was also assumed that full payload capacity would be retained. Finally, the take-off gross weight was calculated and the aircraft range determined using the Breguet range equation.

Block diagrams of the systems considered in this study are shown in Figures 5 to 7 . In the liquid hydrogen-fueled PEM system (Figure 5), liquid hydrogen is store in an insulated cryogenic tank. The hydrogen is first passed through a heat exchanger to vaporize the fuel and then through a humidifier to humidify the gas before entering the fuel cell. On the air side, ambient air is compressed in a single stage compressor before passing through an aftercooler to remove the heat of compression. The air then passes through a humidifier before entering the fuel cell. A heat exchanger removes the waste heat from the fuel cell. This waste heat may be used to preheat the hydrogen in an optimized system. Finally, a separator removes the water from the fuel cell air exit stream. The fuel cell stack is sized to provide the $60 \mathrm{~kW}$ to the electric motor as well as the additional power required by the compressor, which is the most powerintensive ancillary. This system takes advantage of the PEM technology, which is the most advanced, lightest weight fuel cell technology for mobile applications. 
Figure 6 shows the direct methanol PEM system. The system is similar to the previous system, except that the methanol is fed directly to the fuel cell stack and is internally reformed into hydrogen. This feature eliminates the need for a separate fuel processing unit, which would add weight to the system. Again, the fuel cell is sized to provide $60 \mathrm{~kW}$ to the motor as well as the power required by the compressor. In addition to benefiting from the advancements in PEM technology, methanol provides an increase in stored hydrogen per unit volume as compared to liquid hydrogen. Methanol is also a liquid at room temperature, which allows for easier ground handling.

The final system, a direct internal reforming SOFC/turbine hybrid with liquid methane fuel, is shown in Figure 7. Since direct reforming of natural gas has been demonstrated in tubular solid oxide systems and designs have been proposed for similar planar stacks, liquid methane was chosen as the fuel for this system. Like methanol, liquid methane also provides a more efficient means of storing hydrogen. As in the direct methanol system, the ability to reform the fuel in the fuel cell stack eliminates the weight associated with an external fuel processing unit.

In this concept, liquid methane is pumped to a heat exchanger where the methane is vaporized and heated to the fuel cell operating temperature. Ambient air is compressed and also sent through a heat exchanger to heat the stream to the fuel cell temperature. The methane is converted to hydrogen and $\mathrm{CO}$ in the fuel cell stack, both of which are used as fuel. Excess methane and air exiting from the fuel cell stack are burned and expanded in a turbine. The turbine exhaust stream is split and passed through the air and methane heat exchangers to provide heat to the incoming fuel cell streams. The turbine is connected via a shaft to the air compressor and a generator. In this arrangement, the turbine provides power to the compressor. The fuel cell and turbine/generator combine to provide the $60 \mathrm{~kW}$ required by the motor. Because of the amount of heat produced and consumed within this system, thermal integration of the components is an important consideration in the optimization of the system.
Since the SOFC planar technology is currently at a low level of development, performance predictions for the direct reforming stack were based on extrapolations from current state-ofthe-art to a timeframe of twenty to thirty years into the future in order to assess the ultimate potential of the technology. ${ }^{6}$ It was assumed that the cell weight for the direct reforming technology was equivalent to the weight of the lightest state-of-the-art hydrogen-air cells available today. It was also assumed that the performance with direct reformation was comparable to the best performance currently available for hydrogen-air technology.

\section{Discussion of Results}

Figure 8 summarizes the results of the analysis. The bars on the graph represent the total aircraft weight while the diamond symbols indicate the calculated range for that particular system. The BanBi baseline is shown at a gross take-off weight of $992 \mathrm{lbs}$ with a range of approximately $840 \mathrm{~nm}$ using 88 liters of iso-octane.

The gross take-off weight is met with the PEM fuel cell system fueled by liquid hydrogen. However, the constraint of the 88 liter fuel tank volume results in a range that is approximately $1 / 4$ that of the baseline case, illustrating the challenges associated with hydrogen as a fuel. The volume available in the aircraft for hydrogen storage is a critical parameter. In order for a hydrogen-fueled aircraft to be practical, novel hydrogen storage techniques must be investigated and employed.

The direct methanol case shows an improvement in range over the baseline case but exceeds the gross take-off weight. Although the empty weight of the aircraft is essentially the same for both PEM systems, the methanol fuel weight is much heavier than that of liquid hydrogen due to its higher density, resulting in a heavier gross take-off weight.

The most promising system is the direct internal reforming SOFC/turbine hybrid system. This system has the potential to achieve the baseline gross take-off weight while exceeding the range. This is the most advanced system considered with the most aggressive fuel cell performance projections. 
However, it is possible to trade fuel weight for fuel cell weight and/or system performance to relax the constraints on the fuel cell technology and still achieve comparable range to the BanBi baseline aircraft.

\section{Summary}

A top-level study was performed to assess the impact of $\mathrm{PEM} /$ liquid hydrogen, direct methanol PEM, and SOFC-hybrid fuel cell architectures on aircraft take-off weight and range for a small fuel cell-powered aircraft. Based on the study methodology, the SOFChybrid system appears to offer the most potential in terms of achieving an acceptable take-off weight and range. This is due to a number of factors, including: the use of a hydrocarbon fuel, which is more volumetrically efficient than liquid hydrogen storage; direct internal reforming of the fuel, thus eliminating an external fuel processor; and the ability to extract energy from the hot fuel cell exhaust streams by expanding the gas in a turbine.

\section{References}

1. Larminie, J., Dicks, A., Fuel Cell Systems Explained, John Wiley and Sons, Inc., 2000.

2. Fellows, R., "A Novel Configuration for Direct Internal Reforming Stacks," Journal of Power Sources, 71, 1998, pp. 281-287.

3. Harvey, S.P., Richter, H.J., "A Detailed Study of a Gas Turbine Cycle With An Integrated Internal Reforming Solid Oxide Fuel Cell," AIAA-94-4231-CP, 1994.

4. Hassman, K., "SOFC Powerplants, the Siemens-Westinghouse Approach," Fuel Cells 2001, 1, No. 1, pp. 78-84.

5. Freeh, J., Berton, J., Ficher, K, "Emissionless aircraft: Requirements and Challenges ZeroCO $\mathrm{CHO}_{2}$ Study," Presentation, NASA Glenn Research Center, October 1, 2002.

6. "Assessment of Solid Oxide Fuel Cell technology: Comparison of Alternative Design Approaches," EPRIsolutions, Palo Alto, CA: 2002. 1003966.

7. Weast, R. (editor), CRC Handbook of Chemistry and Physics, 62nd Edition, CRC Press, Inc., 1981.

8. Yaws, C., Chemical Properties Handbook, McGraw Hill, 1999.

Table 1: BanBi Weight Statement with Rotax 912 Engine

\begin{tabular}{|l|c|}
\hline \multicolumn{1}{|c|}{ Component } & Weight, Ibs \\
\hline Total Structure & 196 \\
\hline Systems + Equipment & 96 \\
\hline Engine + Accessories & 128 \\
\hline Gearbox & 37 \\
\hline Propeller & 35 \\
\hline Cowl + Mounts & 14 \\
\hline Fuel Tank(s) & 19 \\
\hline Empty Weight (Ibs) & $\mathbf{5 2 4}$ \\
\hline Pilot & 170 \\
\hline Additional Payload & 159 \\
\hline Fuel Weight & 139 \\
\hline Takeoff Gross Weight (Ibs) & $\mathbf{9 9 2}$ \\
\hline
\end{tabular}




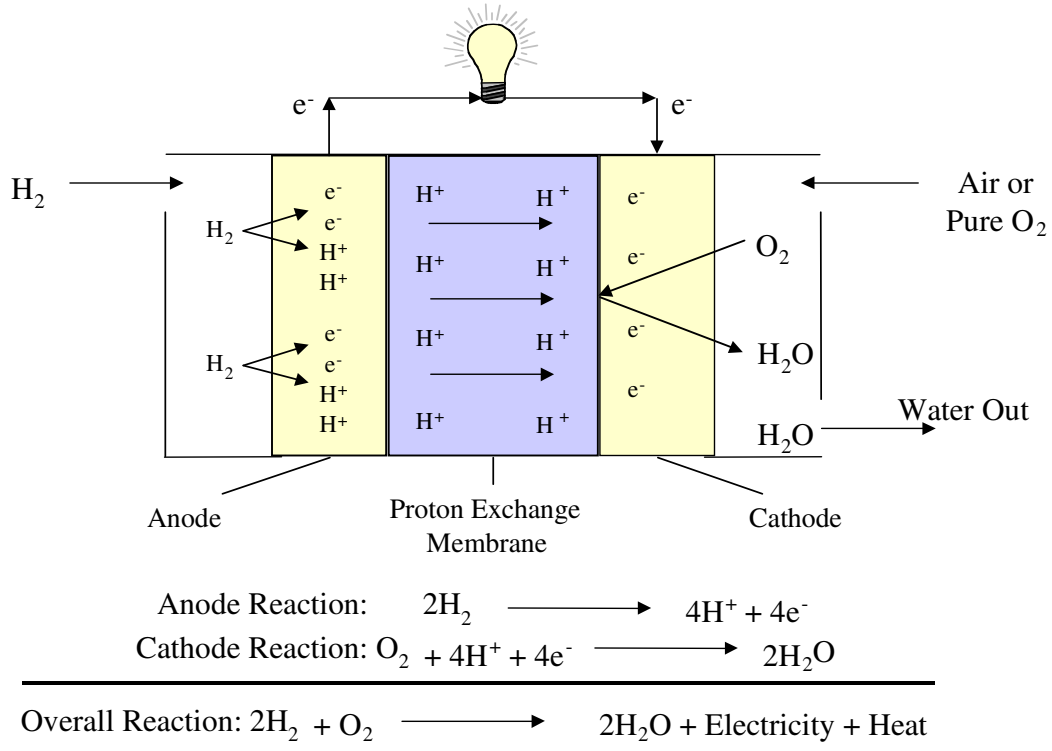

Figure 1: Proton Exchange Membrane Fuel Cell Diagram

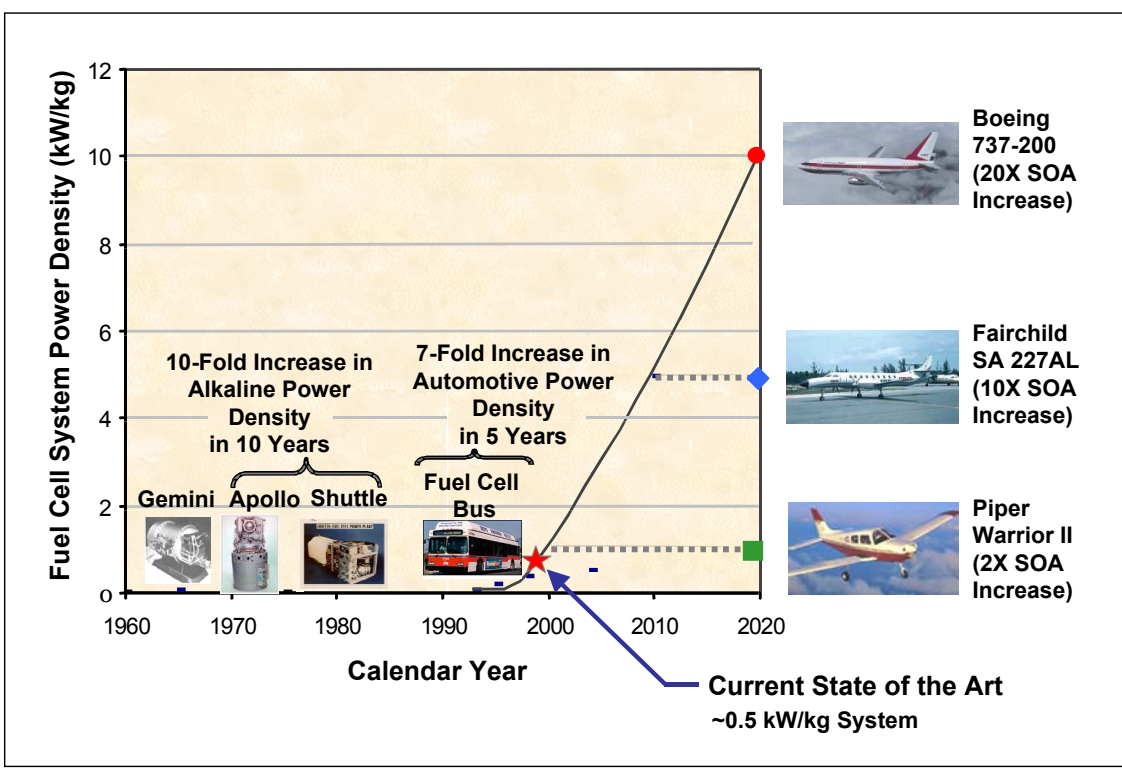

Figure 2: Advances in Fuel Cell Power Density Required to Enable Electric Propulsion 


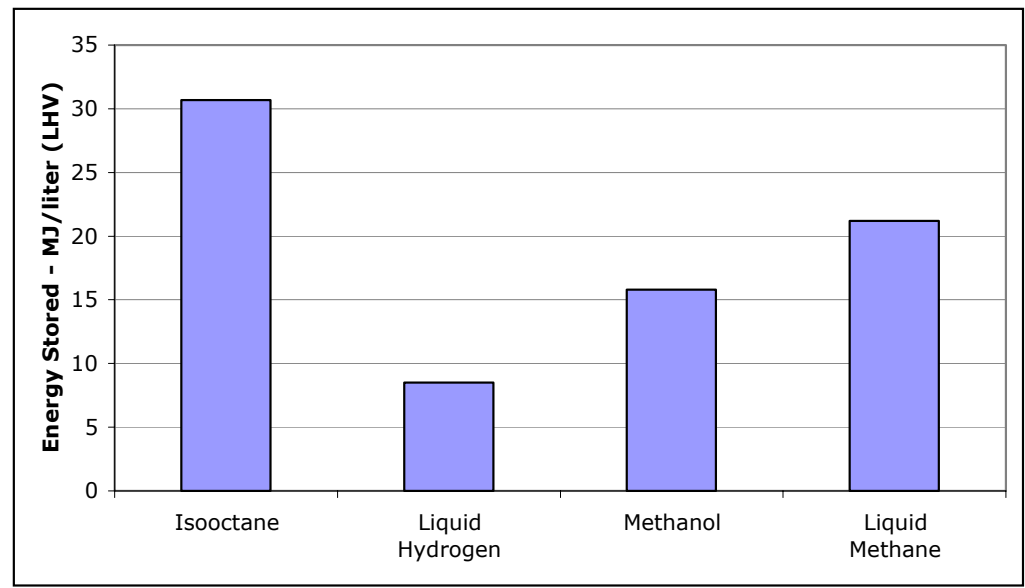

Figure 3: Energy Stored per Liter for Various Liquid Fuels ${ }^{7,8}$

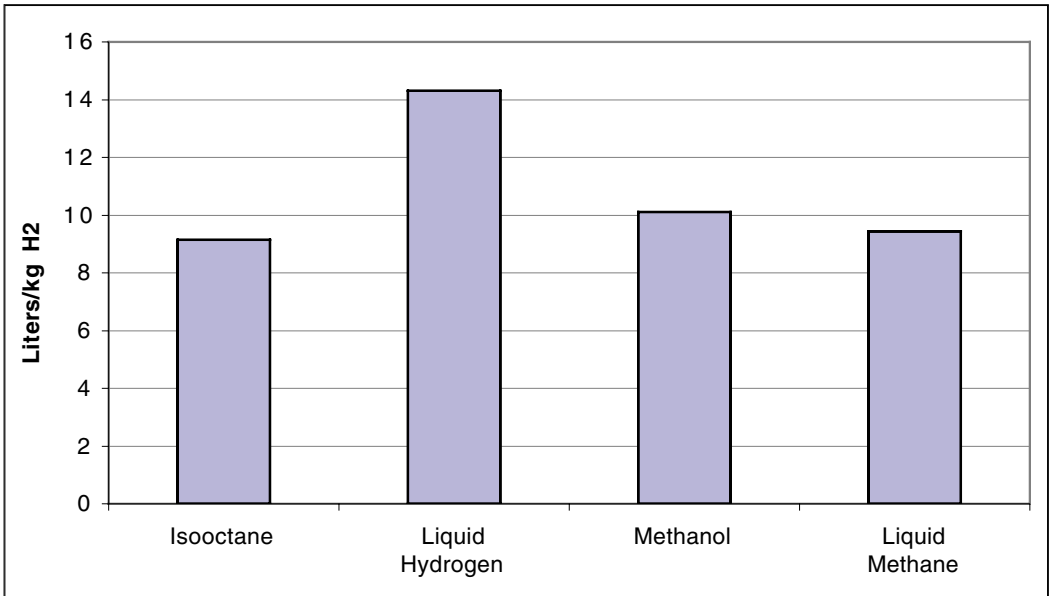

Figure 4: Volume Required to Store $1 \mathrm{~kg}$ of Hydrogen

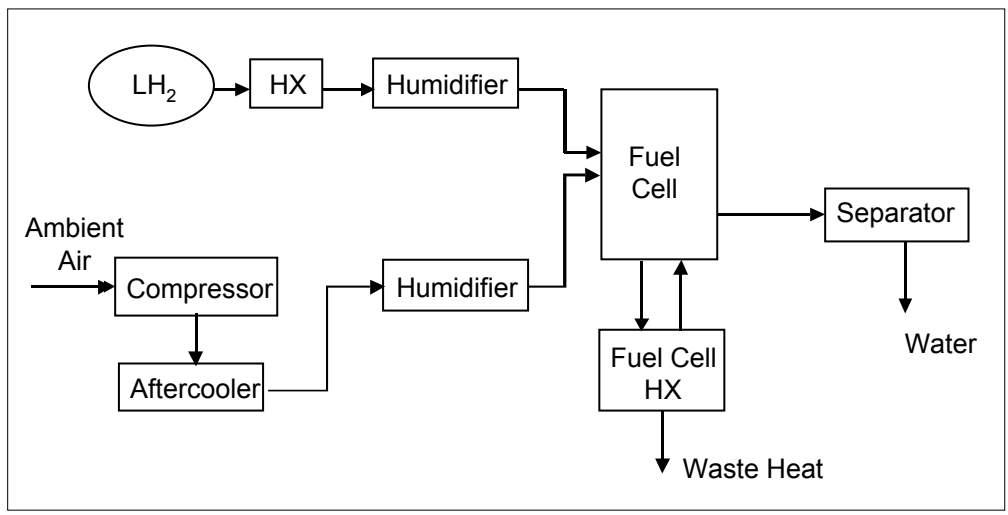

Figure 5: Block Diagram of Liquid Hydrogen PEM Fuel Cell 


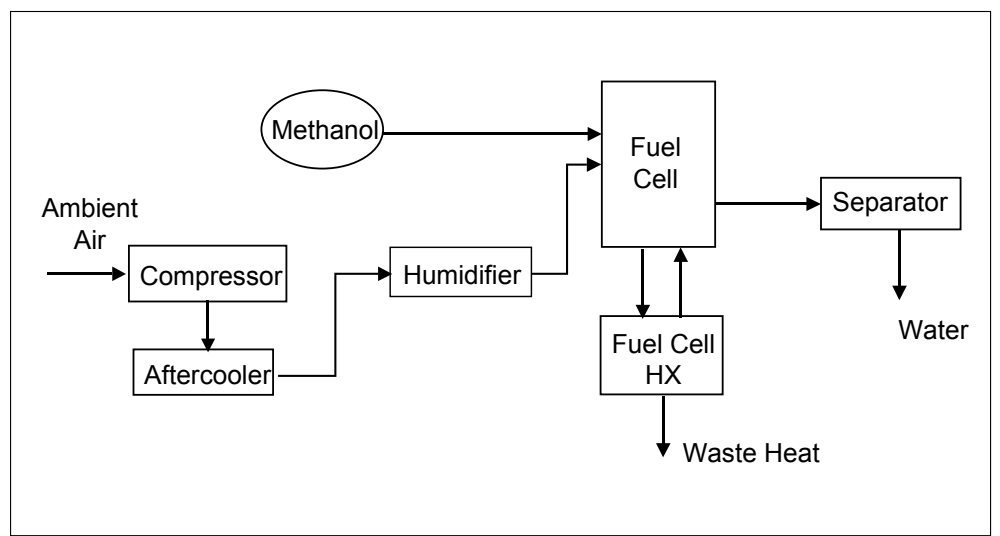

Figure 6: Block Diagram of Direct Methanol PEM Fuel Cell

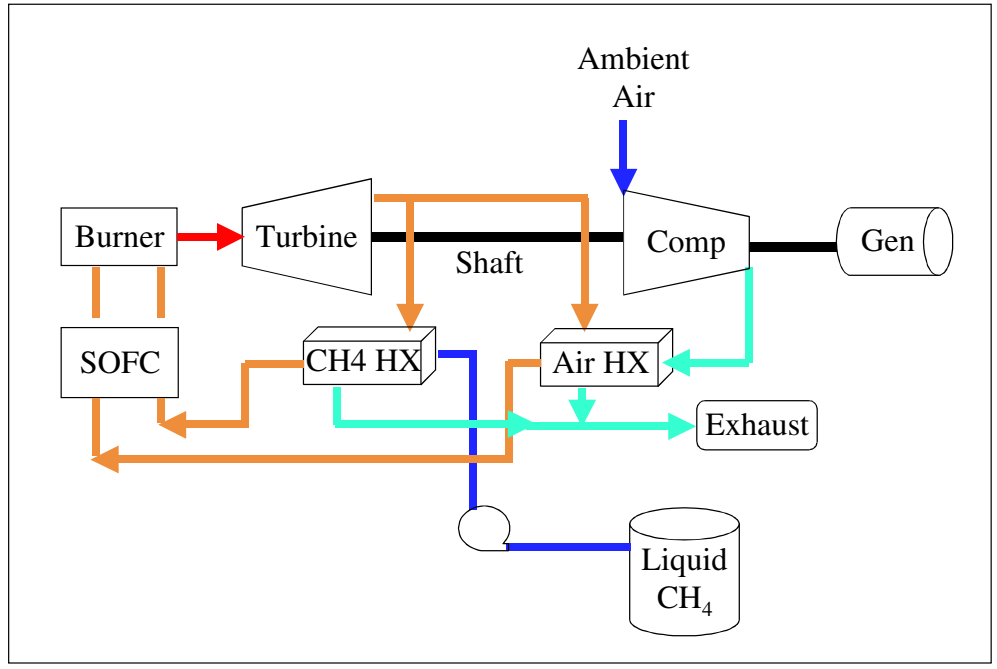

Figure 7: Block Diagram of SOFC/Turbine Hybrid System

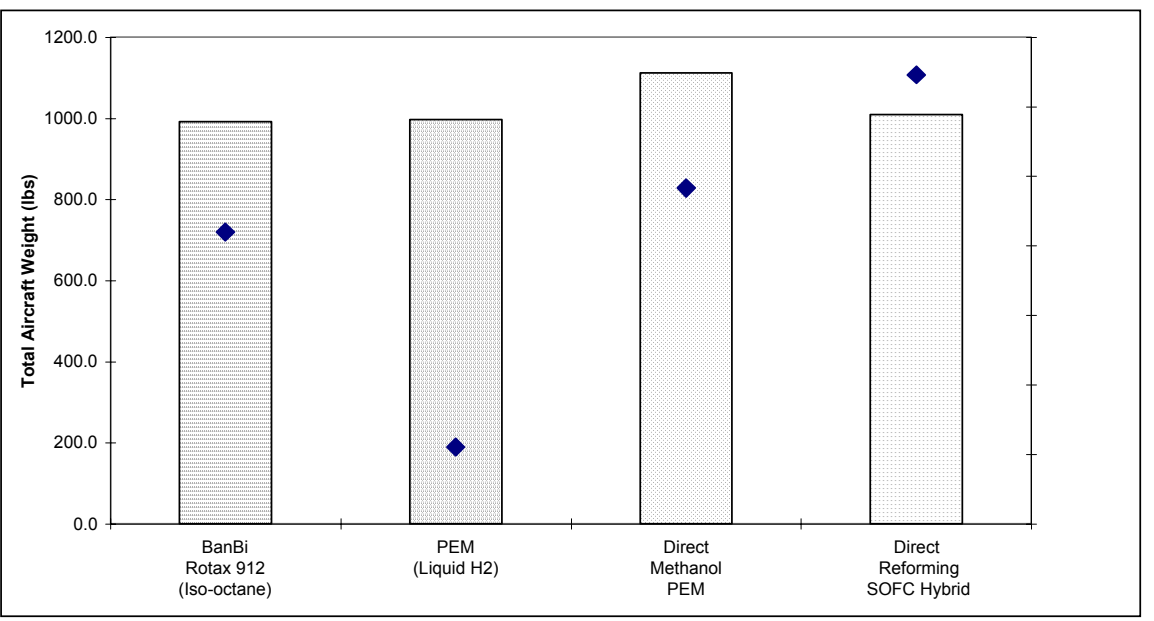

Figure 8: Total Aircraft Weight and Range for Various System Configurations 

Public reporting burden for this collection of information is estimated to average 1 hour per response, including the time for reviewing instructions, searching existing data sources, gathering and maintaining the data needed, and completing and reviewing the collection of information. Send comments regarding this burden estimate or any other aspect of this collection of information, including suggestions for reducing this burden, to Washington Headquarters Services, Directorate for Information Operations and Reports, 1215 Jefferson Davis Highway, Suite 1204, Arlington, VA 22202-4302, and to the Office of Management and Budget, Paperwork Reduction Project (0704-0188), Washington, DC 20503.

\begin{tabular}{|l|l|l|}
\hline 1. AGENCY USE ONLY (Leave blank) & $\begin{array}{c}\text { 2. REPORT DATE } \\
\text { June } 2003\end{array}$ & $\begin{array}{r}\text { 3. REPORT TYPE AND DATES COVERED } \\
\text { Technical Memorandum }\end{array}$ \\
\hline
\end{tabular}

4. TITLE AND SUBTITLE

5. FUNDING NUMBERS

Fuel Cell Propulsion Systems for an All-Electric Personal Air Vehicle

6. AUTHOR(S)

Lisa L. Kohout and Paul C. Schmitz

WBS-22-708-87-11

\section{PERFORMING ORGANIZATION NAME(S) AND ADDRESS(ES)}

National Aeronautics and Space Administration

John H. Glenn Research Center at Lewis Field

Cleveland, Ohio 44135-3191

8. PERFORMING ORGANIZATION REPORT NUMBER

E-13942

\section{SPONSORING/MONITORING AGENCY NAME(S) AND ADDRESS(ES)}

National Aeronautics and Space Administration

Washington, DC 20546-0001

10. SPONSORING/MONITORING AGENCY REPORT NUMBER

NASA TM-2003-212354

AIAA-2003-2867

\section{SUPPLEMENTARY NOTES}

Prepared for the International Air and Space Symposium and Exposition cosponsored by the American Institute of Aeronautics and Astronautics and the International Council of the Aeronautical Sciences, Dayton, Ohio, July 14-17, 2003. Lisa L. Kohout, NASA Glenn Research Center; Paul C. Schmitz, Power Computing Solutions, Inc., Avon, Ohio 44011. Responsible person, Lisa L. Kohout, organization code 5420, 216-433-8004.

12a. DISTRIBUTION/AVAILABILITY STATEMENT

12b. DISTRIBUTION CODE

Unclassified - Unlimited

Subject Category: 07

Distribution: Nonstandard

Available electronically at http://gltrs.grc.nasa.gov

This publication is available from the NASA Center for AeroSpace Information, 301-621-0390.

13. ABSTRACT (Maximum 200 words)

There is a growing interest in the use of fuel cells as a power source for all-electric aircraft propulsion as a means to substantially reduce or eliminate environmentally harmful emissions. Among the technologies under consideration for these concepts are advanced proton exchange membrane and solid oxide fuel cells, alternative fuels and fuel processing, and fuel storage. This paper summarizes the results of a first-order feasibility study for an all-electric personal air vehicle utilizing a fuel cell-powered propulsion system. A representative aircraft with an internal combustion engine was chosen as a baseline to provide key parameters to the study, including engine power and subsystem mass, fuel storage volume and mass, and aircraft range. The engine, fuel tank, and associated ancillaries were then replaced with a fuel cell subsystem. Various configurations were considered including: a proton exchange membrane (PEM) fuel cell with liquid hydrogen storage; a direct methanol PEM fuel cell; and a direct internal reforming solid oxide fuel cell (SOFC)/turbine hybrid system using liquid methane fuel. Each configuration was compared to the baseline case on a mass and range basis.

\section{SUBJECT TERMS}

Fuels cells; Fuels; Aircraft propulsion; Power

\begin{tabular}{|c|c|}
\hline $\begin{array}{c}\text { 17. SECURITY CLASSIFICATION } \\
\text { OF REPORT } \\
\text { Unclassified }\end{array}$ & $\begin{array}{c}\text { 18. SECURITY CLASSIFICATION } \\
\text { OF THIS PAGE } \\
\text { Unclassified }\end{array}$ \\
\hline
\end{tabular}

19. SECURITY CLASSIFICATION OF ABSTRACT

Unclassified 